\title{
The effects of boric acid and citric acid on chiasma frequency and meiotic division in Chorthippus loratus (Acrididae:Orthoptera) males
}

\author{
Serdar KOCA ${ }^{1 *(1)}$, Şifa TÜRKO $\breve{G} L U^{2}$ (iD) \\ ${ }^{1}$ Adnan Menderes University, Science and Arts Faculty, Department of Biology, Aydin, Turkey \\ ${ }^{2}$ Cumhuriyet University, Science Faculty, Department of Biology, Sivas, Turkey
}

\begin{abstract}
In this study, the cytogenetic effects of boric acid and citric acid in meiosis were investigated. Chorthippus loratus species of grasshoppers were treated with boric acid and citric acid sprayed grass at doses of 250,500 and $1000 \mu \mathrm{g} / \mathrm{ml}$ for 24 hours. As a result of the investigations, it was observed that boric acid decreases chiasma frequency in doses of 500 and $1000 \mu \mathrm{g} / \mathrm{ml}$. Differences between $250-500$ and $250-1000 \mu \mathrm{g} / \mathrm{ml}$ doses were statistically significant. In the citric acid treated group, it was found that the frequency of chiasma decreased at doses of 500 and $1000 \mu \mathrm{g} / \mathrm{ml}$. The differences were also significant between 250$500,250-1000$ and 500-1000 $\mu \mathrm{g} / \mathrm{ml}$ doses. In our study, the effects of boric acid and citric acid on chiasma frequency as well as damages like the stickiness of chromosomes, breakage, fragment and anaphase bridge were observed.
\end{abstract}

\section{Article info \\ History:}

Received:12.09.2019

Accepted:20.12.2019

Keywords:

Meiotic division,

Chiasma frequency,

Chromosome damage,

Orthoptera,

Chorthippus loratus.

\section{Introduction}

The food products obtained must be protected and stored for later use. Protecting food is one of the oldest technologies used by people and different ways and environments are used for this. Sugar and salt are the most commonly used substances as food preservatives. Chemical preservatives are also used to protect food. Some food preservatives, especially antimicrobial agents, have been reported to be genotoxic in various test systems [1-3].

Boric acid is a food additive used for antimicrobial purposes. It is used for the sterilization of canned meat, caviar, and fish. Citrus fruits are washed with $5-8 \%$ a solution containing borax and are so protected from the harm of the fungus. Türkoğlu [4] reported that boric acid (20-100 ppm) reduced the mitotic index and caused many mitotic abnormalities. Kumar and Srivastava [5] were investigated that the effect of different concentrations $(0.25,0.50,0.75$ and $1 \%)$ of boric acid and sunset yellow on the chromosomes of Trigonella foenum-graecum L. The results of this study clearly established the genotoxic behaviour of boric acid and sunset yellow. The results obtained for the different doses $(1,2$, and $4 \mathrm{mg} / \mathrm{l})$ of boric acid, citric acid and sodium metabisulphite revealed a significant dose-dependent decrease in the mitotic index and increase in the frequency of chromosome aberrations in the Vicia faba [6]. The human lymphocytes were treated with 400, 600, 800, and $1000 \mu \mathrm{g} / \mathrm{mL}$ concentrations of BA dissolved in dimethyl sulfoxide (DMSO), for $24 \mathrm{~h}$ and $48 \mathrm{~h}$ treatment periods. It has been reported that boric acid induces chromosomal abnormality and sister chromatid formation in human lymphocytes and that it also causes a cytotoxic effect [7].

Citric acid is used as a flavouring and a preservative in foods and beverages. In particular, for biscuits, cakes, instant soup, cheese and cheese products, baby food, chewing gum, margarine, sparkling lemonade, meat, fish, beverages, especially for soft drinks. The Turkish Ministry of health recommended the use of citric acid as $3 \mathrm{~g} / \mathrm{l}$ in food. Although there are several in vivo and in vitro studies showing that citric acid is not mutagenic [8], there are also studies showing that this material reduces mitotic index and increases chromosome damage $[4,6,9]$.

Meiosis is an important process in the life of sexual reproductive organisms. In meiosis, genetic variation is increased by recombination in the genetic material, while the number of chromosomes is halved to maintain genetic material in all generations. The event that provides recombination of the genetic material in meiosis is the occurrence of a chiasma between the 
homologous chromatids of homologous chromosomes in the pachytene phase of Prophase I and the crossing over as a result of this. Various internal and external events are effective on meiosis and chiasma frequency. There are also chemical substances used for various purposes among them [10-12]. Chiasma frequency changed by chemical substances, can be used in genotoxic studies in addition to markers such as mitotic index or micronucleus formation.

No studies have been found on the effect of boric acid and citric acid on chiasm frequency and meiosis in our literature studies. It was therefore aimed to determine the effects of boric acid and citric acid on adult $C h$. loratus males for chiasma frequency and chromosomes.

\section{Materials and Methods}

Ch. loratus type grasshoppers from the Acrididae family of the Orthoptera tribe have been used in our study. Grasshoppers collected from the field (Aydin/Turkey) and brought to the laboratory were treated in cages with freshly grown grass for a week to get used to the environment. When the experiment is to be made, the grasshoppers are left without food and water for 24 hours. At the end of this period, boric acid and citric acid were sprayed at doses of 250, 500 and $1000 \mu \mathrm{g} / \mathrm{ml}$ to let the grasshoppers eat grass for 24 hours in separate cages. The grasshoppers that were used as the control group were treated with water sprayed grass. At the end of the period, the grasshoppers were dissected and the testicles were fixed in a mixture of ethyl alcohol: acetic acid (3:1). The testicular follicles are stained with acetoorcein when the study will be made. In each group, counting on 25 diplotene cells on every 5 grasshoppers has been performed in order to determine the chiasmata. Chromosomal abnormalities and meiosis were noted that occur in preparations besides chiasmata. Statistical analyses were performed for chiasma frequency and the SPSS 17.0 for Windows program was used.

\section{Results}

\subsection{Boric acid}

The mean chiasma frequencies of the Ch. loratus group used as a control and the groups treated with 250, 500, $1000 \mu \mathrm{g} / \mathrm{ml}$ boric acid are shown in Table 1 . The boric acid decreased the chiasma frequency in doses of 500 and $1000 \mu \mathrm{g} / \mathrm{ml}$ compared to the control. It is statistically insignificant despite the increase in the dose of $250 \mu \mathrm{g} / \mathrm{ml}$ compared to the control. The differences between $250 \mu \mathrm{g} / \mathrm{ml}-500 \mu \mathrm{g} / \mathrm{ml}$ and 250 $\mu \mathrm{g} / \mathrm{ml}-1000 \mu \mathrm{g} / \mathrm{ml}$ were found statistically significant.
As a result of the Tukey test, the differences between the doses of $250 \mu \mathrm{g} / \mathrm{ml}$ and $500 \mu \mathrm{g} / \mathrm{ml}-1000 \mu \mathrm{g} / \mathrm{ml}$ with the control were not statistically significant (Table $1)$.

In our study, the damages caused in the chromosomes caused by different doses of boric acid are also observed besides its effects on the chiasm frequency in the Ch. loratus. Abnormalities such as stickiness, fragment formation, and fracture were mostly observed anaphase bridge and lagging chromosome have been found less (Figure $1 \mathrm{~b}-\mathrm{f}$ ).

\subsection{Citric acid}

The mean chiasma frequencies of Ch. loratus' group used as control group and groups treated with 250, 500, $1000 \mu \mathrm{g} / \mathrm{ml}$ citric acid are shown in Table 2 . While as a result of the Tukey test the difference between the control group and the dose of $250 \mu \mathrm{g} / \mathrm{ml}$ was statistically insignificant, there were statistically significant differences between the control group and other doses and doses of $250 \mu \mathrm{g} / \mathrm{ml}, 500$ and 1000 $\mu \mathrm{g} / \mathrm{ml}$ and $500-1000 \mu \mathrm{g} / \mathrm{ml}$ (Table 2).

Besides the effects of different doses of citric acid in the Ch. loratus on the chiasma frequency, aberrations on chromosomes were also observed. Ch. loratus treated with citric acid cause the mostly stickiness and aggregation in the chromosomes and in addition, damages such as anaphase bridge, lagging chromosome, fracture and fragment formation were also encountered (Figure $1 \mathrm{~b}$ and $\mathrm{e}$ ).

Table 1. Ch. loratus groups treated with 250,500 and 1000 $\mu \mathrm{g} / \mathrm{ml}$ boric acid and the Tukey test results between these groups and the control group.

\begin{tabular}{|c|c|c|c|c|}
\hline Application & $\begin{array}{c}\text { Number of } \\
\text { used } \\
\text { individuals }\end{array}$ & $\begin{array}{l}\text { Number } \\
\text { of cells } \\
\text { scored }\end{array}$ & $\begin{array}{c}\text { Mean } \\
\text { chiasma } \\
\text { frequency }\end{array}$ & p* \\
\hline Control- & 5 & 125 & $15.59 \pm 0.63$ & 0.860 \\
\hline $250 \mu \mathrm{g} / \mathrm{ml}$ & 5 & 125 & $15.64 \pm 0.21$ & \\
\hline Control- & 5 & 125 & $15.59 \pm 0.63$ & $p<0.001$ \\
\hline $500 \mu \mathrm{g} / \mathrm{ml}$ & 5 & 125 & $14.64 \pm 0.42$ & \\
\hline Control- & 5 & 125 & $15.59 \pm 0.63$ & $p<0.001$ \\
\hline $1000 \mu \mathrm{g} / \mathrm{ml}$ & 5 & 125 & $14.56 \pm 0.39$ & \\
\hline $250 \mu \mathrm{g} / \mathrm{ml}-$ & 5 & 125 & $15.64 \pm 0.21$ & $p<0.001$ \\
\hline $500 \mu \mathrm{g} / \mathrm{ml}$ & 5 & 125 & $14.64 \pm 0.42$ & \\
\hline $250 \mu \mathrm{g} / \mathrm{ml}-$ & 5 & 125 & $15.64 \pm 0.21$ & $p<0.001$ \\
\hline $1000 \mu \mathrm{g} / \mathrm{ml}$ & 5 & 125 & $14.56 \pm 0.39$ & \\
\hline 500 g/ml- & 5 & 125 & $14.64 \pm 0.42$ & 0.974 \\
\hline $1000 \mu \mathrm{g} / \mathrm{ml}$ & 5 & 125 & $14.56 \pm 0.39$ & \\
\hline
\end{tabular}

*Significant at $\mathrm{p}<0.001$ 
Table 2: Ch. loratus groups treated with 250, 500 and 1000 $\mu \mathrm{g} / \mathrm{ml}$ citric acid and the Tukey test results between these groups and the control group.

\begin{tabular}{|c|c|c|c|c|}
\hline $\begin{array}{c}\text { Applicatio } \\
n\end{array}$ & $\begin{array}{c}\text { Number } \\
\text { of used } \\
\text { individual } \\
s\end{array}$ & $\begin{array}{l}\text { Numbe } \\
r \text { of } \\
\text { cells } \\
\text { scored }\end{array}$ & $\begin{array}{c}\text { Mean } \\
\text { chiasma } \\
\text { frequency }\end{array}$ & P* \\
\hline Control- & 5 & 125 & $15.54 \pm 0.58$ & 0.958 \\
\hline $250 \mu \mathrm{g} / \mathrm{ml}$ & 5 & 125 & $\begin{array}{c}1 \\
15.61 \pm 0.38 \\
6\end{array}$ & \\
\hline Control- & 5 & 125 & $15.54 \pm 0.58$ & $p<0.00$ \\
\hline $500 \mu \mathrm{g} / \mathrm{ml}$ & 5 & 125 & $\begin{array}{c}1 \\
14.72 \pm 0.62 \\
4\end{array}$ & 1 \\
\hline Control- & 5 & 125 & $15.54 \pm 0.58$ & $p<0.00$ \\
\hline 1000 & 5 & 125 & 1 & 1 \\
\hline$\mu \mathrm{g} / \mathrm{ml}$ & & & $\begin{array}{c}14.10 \pm 0.24 \\
5\end{array}$ & \\
\hline $250 \mu \mathrm{g} / \mathrm{ml}-$ & 5 & 125 & $15.61 \pm 0.38$ & $p<0.00$ \\
\hline $500 \mu \mathrm{g} / \mathrm{ml}$ & 5 & 125 & $\begin{array}{c}6 \\
14.72 \pm 0.62 \\
4\end{array}$ & 1 \\
\hline $250 \mu \mathrm{g} / \mathrm{ml}-$ & 5 & 125 & $15.61 \pm 0.38$ & $p<0.00$ \\
\hline $1000 \mu \mathrm{g} / \mathrm{ml}$ & 5 & 125 & $\begin{array}{c}6 \\
14.10 \pm 0.24 \\
5\end{array}$ & 1 \\
\hline 500 mg/ml- & 5 & 125 & $14.72 \pm 0.62$ & $p<0.00$ \\
\hline $1000 \mu \mathrm{g} / \mathrm{ml}$ & 5 & 125 & $\begin{array}{c}4 \\
14.10 \pm 0.24 \\
5\end{array}$ & 1 \\
\hline
\end{tabular}

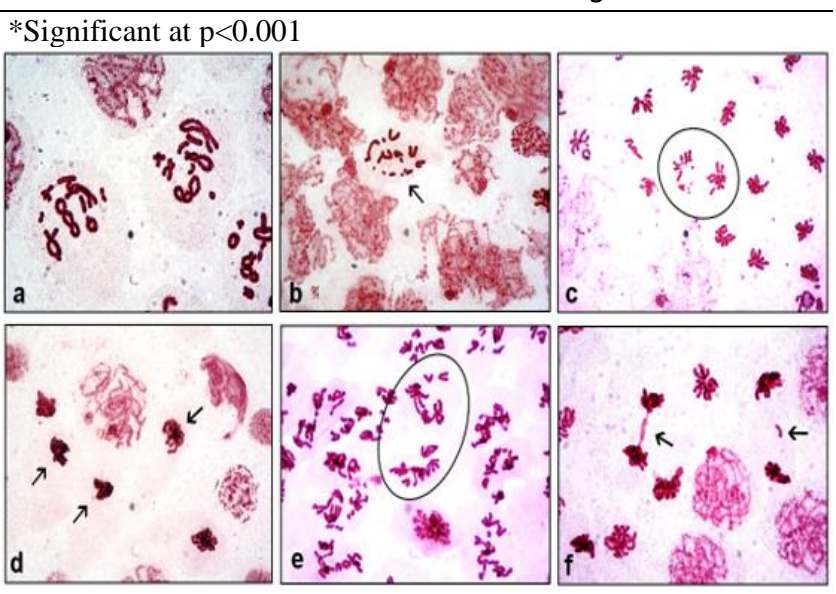

Fig.1. a; Normal diploten cells, b; stickiness and disturbed, c; fragmentation, d; sticky chromosomes, e; unequal seperation and fragmentation, f; anaphase bridge and laggard chromosome

\section{Discussion}

The chiasma frequency is under the influence of many internal and external factors. Shaw [13] has shown that the environmentally uncovered variance forms $40 \%$ of the total variance of the chiasma frequency in Schistocerca gregaria. They act on chiasma frequency in chemical compounds. It is thought that these compounds which are affecting nucleic acid and protein synthesis metabolism may affect the frequency of chiasma. Because meiotic cells are very active in terms of nucleic acid and protein synthesis. These syntheses are thought to be related to the formation of a chiasma.

Chemical compounds generally cause a reduction in chiasma frequency. It has been observed in Capsicum annuum that ethyl methane sulfonate (EMS), diethyl sulphate (DES) and hydroxylamine (HA) lead to a decrease in chiasma frequency [14]. It was determined that 2,4-D, sprayed on the grass with various doses to $S$. gregaria, caused a significant decrease in chiasma frequency compared to the control group [11]. It was determined that Maleic hydrazide $(\mathrm{MH})$ which was treated by spraying the grass with a dose of $10-5 \mathrm{M}$ for 24 hours was found to cause a significant decrease in the chiasma frequency in the Chorthippus dorsatus compared to the control group and 10-4 M MH [12]. And in this study, it was observed that the groups that were treated with doses of 500 and $1000 \mu \mathrm{g} / \mathrm{ml}$ out of the groups which were treated with $250,500,1000$ $\mu \mathrm{g} / \mathrm{ml}$ of boric acid significantly decreased the chiasma frequency according to the control group and doses of $250 \mu \mathrm{g} / \mathrm{ml}$. It was determined that 500 and $1000 \mu \mathrm{g} / \mathrm{ml}$ doses of citric acid applied in the same to the $C h$. loratus caused significant decreases in the chiasma frequency according to the control group and 250 $\mu \mathrm{g} / \mathrm{ml}$ group.

It has been observed that chemical compounds sometimes do not have any effect on the chiasm frequency or that they increase the frequency of chiasm. Actinomycin-D, whose effect on the two stocks of $S$. gregaria was investigated, was found to increase the chiasma frequency in the first stock which has a low chiasm frequency and that it has no effect on the chiasma frequency in the second stock which is normal [10]. 2,4-Dichlorophenoxy acetic acid (2,4-D) applied to $S$. gregaria by induction resulted in a reduction in the chiasm frequency, while 2,4-D given by injection to the abdomen did not cause any change on the chiasma frequency [11]. While the 10-5 $\mathrm{M}$ dose of maleic hydrazide applied to the Ch. dorsatus caused a significant reduction in the chiasma frequency compared to the control group and to 10-4 M, the 10-4 $\mathrm{M}$ dose and the same doses applied on the $C h$. brunneus did not cause any change in the chiasma frequency compared to the control group [12]. It was observed that the dose of $250 \mu \mathrm{g} / \mathrm{ml}$ of the Ch. loratus which was applied with boric acid and citric acid did not lead to a change in the chiasma frequency compared to the control group. 
In our study, it was observed that different doses of boric acid and citric acid have effects on the chiasma frequency in the Ch. loratus and that they also damage the chromosomes. Abnormalities such as stickiness, fragment formation, and fracture were mostly observed in the chromosomes of the Ch. loratus treated with boric acid. Anomalies such as the anaphase bridge and a lagging chromosome have been found less in amount. Stickiness in chromosomes has been identified as a common feature of many chemical compounds $[11,15$, 16]. Some researchers have observed that they have similar effects on boric acid and citric acid $[4,17]$. Our observations in the Ch. loratus are consistent with these findings. Chromosome stickiness reflects highly toxic effects of the irreversible type, often leading to cell death. It has been pleaded that stickiness in chromosomes is formed by subchromatid bridges [18]. Pathak et al. [19] pleaded that some of the clastogenic agents did not directly affect DNA, but had indirect effects due to the chromosome stickiness. The reason for the stickiness is due to the coherence and penetration of submicroscopic fibrils [19]. The formation of the stickiness of boric acid and citric acid in the chromosomes requires us to accept them as clastogenic agents.

It is understood from our results that boric acid and citric acid cause chromosome breakage and anaphase bridges. Similar effects of many chemicals have been determined by different researchers. Studies with Allium cepa showed us that boric acid and citric acid cause chromosome breakage [4, 17]. Our results support these findings. Chromosome breaks, fragment changes and stickiness formed by many chemicals, cause anaphase bridges and anaphase fragments $[1,11$, $12,20-22]$.

From this test, we can clearly see the chromotoxic effects of boric acid and citric acid, which are commonly used in the food industry. Therefore, we need to be careful when using these chemicals as a preservative in foods. Additional studies of clastogenicity and genotoxicity of these food preservatives may also produce more interesting results.

\section{Conflict of interest}

The authors declare that they have no conflict of interest.

\section{References}

[1] Rencüzoğulları E., Kayraldız A., Ila H. B., Çakmak T., Topaktaş M., The Cytogenetic Effects of Sodium Metabisulfite, a Food
Preservative in Root Tip Cells of Allium cepa $\mathrm{L}$. Turk J Biol., 25 (2001) 361-370.

[2] Gömürgen A. N., Cytological effect of the potassium metabisulphite and potassium nitrate food preservative on root tips of Allium cepa $\mathrm{L}$., Cytologia ,70 (2005) 119-128.

[3] Mpountoukas P., Vantarakis A., Sivridis E., Lialiaris T., Cytogenetic study in cultured human lymphocytes treated with three commonly used preservatives, Food chem. Toxicol., 46 (7) (2008) 2390-2393.

[4] Türkoğlu Ş., Genotoxicity of five food preservatives tested on root tips of Allium cepa L., Mutation Research, 626 (2007) 4-14.

[5] Kumar G. and Srivastava N., Genotoxic effects of two commonly used food additives of boric acid and sunset yellow in root meristems of Trigonella foenum-graecum, Iran. J. Environ. Health. Sci. Eng., 8(4) (2011) 361-366.

[6] Pandey R. M. and Santosh U., Impact of food additives on mitotic chromosomes of Vicia faba L. Caryologia, 60(4) (2007) 309-314.

[7] M., Topaktas M. and Rencuzogullari E., The effects of boric acid on sister chromatid exchanges and chromosome aberrations in cultured human lymphocytes, Cytotechnology, 56(2) (2008) 91-96.

[8] HERA, Citric acid and salts, Edition 1.0, (2005), pp 1-6.

[9] Yılmaz S., Ünal, F., Yüzbaşıŏlu D., Aksoy, H., Clastogenic effects of food additive citric acid in human peripheral lymphocytes, Cytotechnology, 56 (2) (2008) 137-144.

[10] Craig-Cameron T. A., Actinomycin-D and chiasma frequency in Schistocerca gregaria (Forskal), Chromosoma, 30 (1970) 169-179.

[11] Koca S. and Bilaloğlu R., The effects of 2,4-D on Schistocerca gregaria Forskal males and frequency of meiotic division. IX. National Biology Congress, Sivas, 1(1988) 287-293.

[12] Koca S. and Bilaloğlu R., Effect of maleic hydrazide on chiasm frequency and meiotic cleavage in Chorthippus dorsatus and Ch. brunneus males. Cumhuriyet Sci. J, 19 (1996) 1-9.

[13] Shaw D. D., Genetic and environmental components of chiasma control, Chromosoma, 46 (1974) 365-374.

[14] Abbagani S. and Subhash K., Effect of Chemical Mutagens on Chiasma Frequency in Capsicum annuum L., Cytologia, 49(2) (1984) 415-419.

[15] Al-Najjar N. R. and Soliman A. S., Cytological effects of herbicides 1. Effect of 2,4-D and 
2,4,5-T on meiotic cells of wheat and two related species, Cytologia, 47 (1982) 53-61.

[16] Bilaloğlu R., The effect of 2,4-D on Vicia faba $\mathrm{L}$ chiazma frequency and meiotic division, Cumhuriyet Sci. J., 6(2) (1988) 151-163.

[17] Dönbak L., Rencüzoğulları E., Topaktaş M., The cytogenetic effects of the food additive boric acid in Allium cepa L., Cytologia, 67 (2002) 153-157.

[18] Klasterska I., Natarajan A. T., Ramel C., An interparation of the origin of subchromatid aberrations and chromosome stickiness as a category of chromatid aberrations, Hereditas, 83 (1976) 153-162.

[19] Pathak S., McGill M., Hsu T. C., Actinomycin$\mathrm{D}$ effect on mitosis and chromosomes. Sticky chromatids and localized lesions, Chromosoma, 50 (1975) 79-88.

[20] Tomkins D. J. and Grant W. F., Monitoring natural vegetation for herbicide-induced chromosomal aberrations, Mutat. Res., 36 (1976) 73-84.

[21] Kumar P. and Panneersalvam N., Cytogenetic studies of food preservative in Allium cepa root meristem cells, Facta Universitatis, 14 (2) (2007) 60-63.

[22] Türkoğlu Ş., Evaluation of genotoxic effects of sodium propionate, calcium propionate and potassium propionate on the root meristem cells of Allium cepa, Food and Chemical Toxicology, 46 (2008) 2035-2041. Int., 37(2011)97-104. 